\title{
ARTHRITIS AS A MANIFESTATION OF INFECTIVE ENDOCARDITIS
}

Uvarova K. H.

Introduction. Diagnosis of infective endocarditis is a challenging task for clinicians. The issue of early infective endocarditis detection is topical, since the mortality rate of this pathological condition is high; also, along with the classic symptoms of the disease, its atypical manifestations, so-called «masks» of infective endocarditis, often occur.

Objectives. The purpose of the work is to investigate one of infective endocarditis manifestations in the form of monoarthritis on the clinical case basis.

Materials and methods. The medical history, the laboratory and instrumental findings, Guidelines for the management of infective endocarditis 2015; Infective Endocarditis in Adults: Diagnosis, Antimicrobial Therapy, and Management of Complications, AHA 2015 (including update 2016).

Results. The patient, born in 1952, complains of the right foot pain, fever with chills, general weakness. Considers herself ill for 3 weeks. In connection with the right foot pain intensification, the patient was taken to a multidisciplinary hospital by the ambulance team and hospitalized to the therapeutic department. The anamnesis vitae is notable for her undergoing a procedure for curettage of the uterine cavity for an endometrial polyp half a year before the admission. The main diagnosis: Active mitral valve endocarditis due to Streptococcus haemolyticus. Mitral valve regurgitation stage III. Chronic coronary syndrome. Heart failure with preserved ejection fraction (EF $68 \%$ ). NYHA class II. Concomitant diagnosis: Mild anemia. Reactive arthritis. Deforming osteoarthrosis of the ankle joint. The treatment included: meronem $1 \mathrm{~g} 3$ times daily intravenously (IV) and linezolidine $600 \mathrm{mg} 2$ times a day per os during 4 weeks; detoxification, cardiotropic, antiplatelet and anticoagulant therapy; proton pump inhibitors, diuretics, antifungal drugs.

Conclusion. Diagnosis of infective endocarditis is very challenging despite the presence of the specially developed diagnostic criteria. Given the polymorphic clinical manifestations of the disease and multiple organ damage, clinicians should be wary of the presence of infective endocarditis in patients with corresponding risk factors.

KEY WORDS: infective endocarditis, clinical diagnosis, arthritis

\section{INFORMATION ABOUT AUTHORS}

Karyna Uvarova, Assistant of Department of Propaedeutics of Internal Medicine and Physical Rehabilitation of V. N. Karazin Kharkiv National University, 6, Svobody Sq, Kharkiv, Ukraine, 61022, e-mail: karinaguvarova@karazin.ua, ORCID ID: https://orcid.org/0000-0003-3135-0778

\section{INTRODUCTION}

The annual incidence of infective endocarditis (IE) ranges from 1.5 to 11.6 cases per 100,000 person-years [1]. Given the high mortality rate from IE (survival at the stage of inpatient treatment is 14-22\%; within a year after diagnosis, even with the most currently effective therapy, - 20-30\% [2]), it is extremely important to detect this disease at the early possible stage of its development. To accomplish the latter task, one should remember and consider atypical symptoms of the manifestation of this pathological condition (IE «masks») in addition to the classical manifestations of IE.

\section{OBJECTIVES}

The purpose of the work is to investigate one of the manifestations of IE in the form of monoarthritis on the basis of the clinical case.

\section{MATERIALS AND METHODS}

The medical history, the laboratory and instrumental findings, Guidelines for the management recommendations of infective endocarditis 2015; Infective Endocarditis in Adults: Diagnosis, Antimicrobial Therapy, and Management of Complications, AHA 2015 (including update 2016).

\section{RESULTS}

Patient O., 67 years old. Upon admission to the hospital complained of pain in the right foot, due to which the patient couldn't stand; 
increase in body temperature up to $40^{\circ} \mathrm{C}$ with chills, general weakness.

Anamnesis morbi. Considers herself ill for the past 3 weeks. About 2 weeks ago, she noticed a periodic increase in body temperature up to $40^{\circ} \mathrm{C}$ during the week, which was accompanied by chills; there was a sharp pain in the ankle joint of the right leg. She was taking paracetamol at the dose of $500 \mathrm{mg}$ 2 times a day; as a result, the temperature was being decreased for a while. 05.11.19 due to intensification of the foot pain the patient called for an ambulance team. She was admitted to the Municipal non-commercial enterprise «Municipal clinical multidisciplinary hospital № 17» of Kharkov City Council and hospitalized to the therapeutic department.

Anamnesis vitae. According to the patient, about 6 months ago she underwent a procedure for curettage of the uterine cavity for an endometrial polyp. Before the first complaints appeared, she had led an active lifestyle, went in for sports (running, skiing). She disclaims pernicious habits, any allergic reactions. Denies hepatitis A, tuberculosis, sexually transmitted diseases. She also negates visiting places endemic for malaria.

Objective examination. General condition is stable. Consciousness is clear, posture is restricted due to severe pain in the right foot. Weight $-62 \mathrm{~kg}$, height $-167 \mathrm{~cm}, \mathrm{BMI}-22,23 \mathrm{~kg} / \mathrm{m}^{2}$. Body temperature is $37.3^{\circ} \mathrm{C}$. Skin is somewhat pale, clean, dry. Mucous membranes are pale pink, clean, wet. Swelling of the right foot is noticed, palpation of the foot is sharply painful. Peripheral lymph nodes are not palpable. Thyroid gland is not enlarged on palpation.

Respiratory system: rhythmic breathing. Respiratory rate is $17 / \mathrm{min}$. On percussion, above both lungs, percussion sound is clear. On auscultation, there is vesicular breathing in the lungs, no adventitious lung sounds.

Cardiovascular system: the apical impulse is determined in the $\mathrm{V}$ intercostal space $1.5 \mathrm{~cm}$ medially from the left midclavicular line, of moderate strength, with an area of about $2 \mathrm{~cm}^{2}$. The borders of relative cardiac dullness are not extended. Heart rate (HR) - 82 bpm. Ps $82 \mathrm{bpm}$, rhythmic, unstressed, of satisfactory filling, the same on the right and left hands. On auscultation, heart sounds are rhythmic, muffled tones are noted. Blood pressure (BP): on the right arm $-130 / 80 \mathrm{~mm} \mathrm{Hg}$, on the left arm $-135 / 84 \mathrm{~mm} \mathrm{Hg}$.
Gastrointestinal system: The tongue is wet, clean. Abdomen is symmetrical, participates in breathing actively. On superficial and deep palpation, the abdomen is soft, painless. The lower edge of the liver is smooth, painless, palpated at the level of the right costal arch. Spleen, kidneys are not palpable. Tapping sign is negative on both sides. Stool and diuresis are not changed.

Laboratory and instrumental tests. The results of laboratory and instrumental studies allowed to reveal: mild anemia, an increase in ESR up to $65 \mathrm{~mm} / \mathrm{h}$, leukocytosis with a shift in the leukocyte formula to the left with the appearance of young forms, toxic granulation of neutrophils; increased level of C-reactive protein up to $204 \mathrm{mg} / \mathrm{l}$; normal values of antistreptolysin $\mathrm{O}$, rheumatoid factor and seromucoids. According to the results of the three sets of blood cultures taken at 30-min intervals, the growth of Streptococcus haemoliticus spp. was obtained with the scale of sensitivity to antibacterial drugs.

Echocardiography: at the bottom of the medial mitral valve (MV) commissure, a threadlike formation of up to $1.5 \mathrm{~cm}$ in length was detected. Vegetation. Defect of the MV leaflet. Low degree dilatation of the left atrium cavity. MV regurgitation stage III. Ejection fraction (EF) $68 \%$.

Chest $X$-ray: without focal and infiltrative changes.

$X$-ray of the right foot in two projections: signs of deforming osteoarthrosis.

The main diagnosis: Active mitral valve endocarditis due to Streptococcus haemoliticus. Mitral valve regurgitation stage III. Chronic coronary syndrome. Heart failure with preserved ejection fraction (EF $68 \%$ ). NYHA class II.

Concomitant diagnosis: Mild anemia. Reactive arthritis. Deforming osteoarthrosis of the ankle joint.

Our patient received antibiotic therapy (meropenem $1 \mathrm{~g} 3$ times daily IV, linezolidine $600 \mathrm{mg} 2$ times daily per os) for 4 weeks, as well as detoxification, cardiotropic, antiplatelet and anticoagulant therapy. Among the side effects during the treatment dizziness was noted. As a result of the therapy, the general condition of the patient improved: body temperature returned to normal, pain in the right foot decreased significantly - the patient moved independently with the help of walkers; there was also a decrease in the level of C-reactive 
protein up to $2.9 \mathrm{mg} / \mathrm{l}$, a decrease in the level of white blood cells and ESR; the three sets of blood culture 4 weeks after the start of treatment did not reveal the growth of microorganisms. Being discharged from the hospital, the patient was sent to the Heart Institute for surgical treatment.

\section{DISCUSSION}

IE is a rare infectious (mainly bacterial) disease that affects endocardium. IE risk factors are diverse. In developing countries, the most common condition predisposing to the occurrence of IE is rheumatic heart disease [3]. Due to the significant prevalence of artificial heart valve and cardioverter-defibrillators implantation, the latter contributes to an increase in the proportion of IE cases [4]. Mitral valve prolapse is also considered to be the predominant predisposing structural heart anomaly in developed countries [5]. Other risk factors include injecting drug use and human immunodeficiency virus infection [2]. Procedures associated with an increased IE risk comprise manipulations of the gums and periapical region of the teeth, as well as perforation of the oral mucosa, and the use of dental implants [6].

In $80 \%$ of cases, streptococci and staphylococci are the causative agents of IE [7], however, recently the proportion of these microorganisms among all pathogens has changed. So, the percentage of Staphylococcus aureus and coagulase-negative staphylococci prevalence increased $[8 ; 9 ; 10]$, while the percentage of IE caused by streptococci of viridans group decreased [10; 17]. In addition, enterococci are the third among the leading causes of IE [11]. In about $10 \%$ of IE cases, blood culture results are negative, mainly due to the use of antibacterial drugs during some time before the examination [7].

Typical clinical manifestations of IE in $90 \%$ are common symptoms of fever with chills, decreased appetite and body weight. In $85 \%$ of patients, cardiac murmurs are heard. Up to $25 \%$ of patients suffer from embolic complications at the time of diagnosis [12]. The classic signs of IE are: Osler nodes (dense painful subcutaneous red nodules on the fingertips), Janeway lesions (small erythematous spots in the palms and soles), Lukin-Libman spots (hemorrhagic rashes on the skin, mucous membranes, conjunctival hemorrhages (spots), retinal hemorrhage), petechiae. In approximately half of IE cases, at least one of these symptoms occurs [13].

Given the multiple organ damage by a systemic infectious process, there is a polymorphic clinical picture of IE, and, consequently, late diagnosis of the disease in view of the low alertness of medical personnel regarding IE. Such «masks» of the pathologic process are pulmonary (in 20-90\% of patients), neurological $(5-10 \%$ of patients), rheumatologic ( $2-4 \%$ of patients), renal (3.5$4.8 \%$ of patients), cardiological (2-4\% of patients), vascular (1.2-3\% of patients), hematological (1.6-2.2\% of patients), «acute abdomen» (0.5-1.5\% of patients), ocular (0.3 $0.5 \%$ of patients) [14].

Due to the activation of immune mechanisms that damage blood vessels in IE, a clinical picture that resembles that of systemic diseases of the connective tissue may develop, which requires differential diagnosis with those. One of IE «masks» is arthritis, the onset of symptoms of which can precede the classic picture of the disease for several months. «Rheumatic» manifestation of IE is observed in approximately 5-9\% of patients, that is usually seen in its subacute course [14]. Most often, the knee and hip joints are affected [15]. In subacute bacterial endocarditis, the damage of musculoskeletal system by the pathogen usually manifests with symptoms of acute septic asymmetric arthritis involving 1-3 joints [16].

\section{CONCLUSIONS}

Despite the developed criteria, the diagnosis of IE is still a difficult task, which is associated with the polymorphism of the clinical picture and multiple organ damage as a result of the generalized infectious process.

\section{REFERENCES}

1. Abdulhak, A., Baddour, L., Erwin, P., Hoen, B., Chu, V., Mensah, G., Tleyjeh, I. (2014). Global and regional burden of infective endocarditis, 1990-2010: a systematic review of the literature. Global Heart, 9(1), 131-143. doi:10.1016/j.mce.2014.01.002.

2. Kaura, A., Dworakowska, D., Dworakowski, R. (2017). Infective endocarditis-Cinderella in cardiology. Kardiol Pol, 75 (10), 965-74. doi:10.1016/j.mce.2014.01.002. 
3. Watt, G., Lacroix, A., Pachirat, O., Bagget, H., Raoult, D., Fournier, P., Tattevin, P. (2015). Prospective comparison of infective endocarditis in Khon Kaen, Thailand and Rennes, France. The American journal of tropical medicine and hygiene, 92(4), 871-874. doi:10.4269/ajtmh.14-0689.

4. Greenspon, A., Patel, J., Lau, E., Ochoa, J., Frisch, D., Ho, R. ... Kurtz, S. (2011). 16-year trends in the infection burden for pacemakers and implantable cardioverter-defibrillators in the United States: 1993 to 2008. Journal of the American College of Cardiology, 58(10), 1001-1006. doi:10.1016/j.jacc.2011.04.033.

5. DeSimone, D., DeSimone, C., Tleyjeh, I., Correa de Sa, D., Anavekar, N., Lahr, B. ... Baddour, L. (2015). Association of mitral valve prolapse with infective endocarditis due to viridans group streptococci. Clinical Infectious Diseases, 61(4), 623-625. doi:10.1093/cid/civ375.

6. Chen, T., Yeh, Y., Chien, K., Lai, M., Tu, Y. (2018). Risk of infective endocarditis after invasive dental treatments: case-only study. $\quad$ Circulation, $356-363$. doi:10.1161/CIRCULATIONAHA.117.033131.

7. Holland, T., Baddour, L., Bayer, A., Hoen, B., Miro, J., Fowler, V. (2016). Infective endocarditis. Nature reviews. Disease primers, 2, 16059. doi:10.1038/nrdp.2016.59.

8. Le Moing, V., Alla, F., Doco-Lecompte, T., Delahaye, F., Piroth, L., Chirouze, C. ... Vandenesch, F. (2015). Staphylococcus Aureus bloodstream infection and Endocarditis-a prospective cohort study. PloS one, 10(5), e0127385. doi:10.1371/journal.pone.0127385.

9. Federspiel, J., Stearns, S., Peppercorn, A., Chu, V., Fowler, V. (2012). Increasing US rates of endocarditis with Staphylococcus aureus: 1999-2008. Archives of internal medicine. 172(4), 363-365. doi:10.1001/archinternmed.2011.1027.

10. Duval, X., Delahaye, F., Alla, F., Tattevin, P., Obadia, J., Le Moing, V. ... Chirouze, C. (23012). Temporal trends in infective endocarditis in the context of prophylaxis guideline modifications: three successive population-based surveys. Journal of the American College of Cardiology, 59(22), 1968-1976. doi:10.1016/j.jacc.2012.02.029.

11. Pericás, J., Zboromyrska, Y., Cervera, C., Castañeda, X., Almela, M., Garcia-De-La-Maria, C. ... Llopis, J. (2015). Enterococcal endocarditis revisited. Future microbiology, 10(7), 1215-1240. doi: $10.2217 / \mathrm{fmb} .15 .46$.

12. Habib, G., Lancellotti, P., Antunes, M., Bongiorni, M., Casalta, J., Del Zotti, F. ... Miro, J. (2015). 2015 ESC guidelines for the management of infective endocarditis: the task force for the management of infective endocarditis of the European Society of Cardiology (ESC) endorsed by: European Association for Cardio-Thoracic Surgery (EACTS), the European Association of Nuclear Medicine (EANM). European heart journal, 36(44), 3075-3128. doi:10.1093/eurheartj/ehv319.

13. Hitzeroth, J., Beckett, N., Ntuli, P. (2016). An approach to a patient with infective endocarditis. SAMJ: South African Medical Journal, 106(2), 145-150. doi:10.7196/SAMJ.2016.v106i2.10327.

14. Lobzin, Yu. V., Levina, A.S. (2015). Klinicheskie maski infekczionnogo endokardita. Zhurnal infektologii, 7(2), 14-20. [Russian]. doi:10.22625/2072-6732-2015-7-2-14-20.

15. Lieber, S., Shmerling. R., Moore, A., Fowler, M., Nasrullah, K., Paz, Z. (2016). Infective Endocarditis with Septic Arthritis: A Single-Center Experience [abstract]. Arthritis Rheumatol, 68 (suppl 10). Retrieved from https://acrabstracts.org/abstract/infective-endocarditis-with-septic-arthritis-a-single-centerexperience/. Accessed February 28, 2020.

16. Soor, P., Sharma, N., Rao, C. (2017). Multifocal septic arthritis secondary to infective endocarditis: a rare case report. Journal of orthopaedic case reports, 7(1), 65. doi:10.13107/jocr.2250-0685.692.

17. Baddour, L., Wilson, W., Bayer, A, Fowler, V., Tleyjeh, I., Rybak, M. ... Bolger, A. (2015). Infective endocarditis in adults: diagnosis, antimicrobial therapy, and management of complications: a scientific statement for healthcare professionals from the American Heart Association. Circulation, 132(15), 14351486. doi:10.1161/CIR.0000000000000296.

\section{АРТРИТ ЯК МАНІФЕСТАЦІЯ ІНФЕКЦІЙНОГО ЕНДОКАРДИТУ}

\section{Уварова К. Г.}

Вступ. Діагностика інфекційного ендокардиту $\epsilon$ важким завданням для лікарів-клініцистів. Проблема раннього виявлення інфекційного ендокардиту стоїть гостро через високий рівень смертності від цього патологічного стану; до того ж, поряд із класичними симптомами захворювання мають місце атипові його прояви, так звані «маски» інфекційного ендокардиту.

Мета роботи. На підставі клінічного випадку розглянути один із варіантів маніфестації інфекційного ендокардиту у вигляді моноартрита. 
Матеріали та методи. Дані анамнезу, лабораторно-інструментального обстеження, Рекомендації Guidelines for the management of infective endocarditis 2015; Infective Endocarditis in Adults: Diagnosis, Antimicrobial Therapy, and Management of Complications, AHA 2015 (including update 2016).

Результати. Пацієнтка, 1952 р. н., скаржиться на біль у правій стопі, лихоманку з ознобом, загальну слабкість. Вважає себе хворою протягом 3 тижнів. У зв'язку з посиленням болю у стопі хвора бригадою швидкої медичної допомоги була доставлена до багатопрофільного стаціонару i госпіталізована до терапевтичного відділення. Анамнез життя заслуговуває на увагу тому, що за півроки до надходження до стаціонару хворій було проведено процедуру кюретажу порожнини матки 3 метою видалення поліпа ендометрію. Був виставлений основний діагноз: Активний бактеріальний ендокардит мітрального клапану, викликаний Streptococcus haemolyticus. Мітральна регургітація III ст. Хронічний коронарний синдром. Серцева недостатність зі збереженою скорочувальною функцією лівого шлуночка (фракція викиду 68 \%). NYHA клас II. Супутній діагноз: Анемія легкого ступеня. Реактивний артрит. Деформуючий остеоартроз гомілкового суглобу. Проведена терапія включала: меронем 1 г 3 рази на добу в/в крапельно і лінезолідін 600 мг 2 рази на день per os протягом 4 тижнів; дезінтоксикаційну, кардіотропну, антиагрегантну та антикоагулянтну терапію; інгібітори протонної помпи, діуретики, протигрибкові препарати.

Висновки. Діагностика інфекційного ендокардиту складає великі труднощі, незважаючи на наявність спеціально розроблених діагностичних критеріїв. 3 огляду на поліморфізм клінічних проявів захворювання і поліорганність ураження, лікарям-клініцистам слід бути пильними щодо наявності інфекційного ендокардиту у пацієнтів з відповідними факторами ризику.

КЛЮЧОВІ СЛОВА: інфекційний ендокардит, клінічна діагностика, артрит

\section{ІНФОРМАЦІЯ ПРО АВТОРА}

Уварова Карина Геннадіївна, асистент кафедри пропедевтики внутрішньої медицини і фізичної реабілітації Харківського національного університету імені В. Н. Каразіна, площа Свободи, 6, Харків, Україна, 61022, e-mail: karinaguvarova@karazin.ua, ORCID ID: https://orcid.org/0000-0003-3135-0778

\section{АРТРИТ КАК МАНИФЕСТАЦИЯ ИНФЕКЦИОННОГО ЭНДОКАРДИТА}

Уварова К. $Г$.

Введение. Диагностика инфекционного эндокардита является трудной задачей для врачейклиницистов. Проблема раннего выявления инфекционного эндокардита стоит остро из-за высокого уровня смертности от данного патологического состояния; к тому же, наряду с классическими симптомами заболевания имеют место атипичные его проявления, так называемые «маски» инфекционного эндокардита.

Цель работы. На основании клинического случая рассмотреть один из вариантов манифестации инфекционного эндокардита в виде моноартрита.

Материалы и методы. Данные анамнеза, лабораторно-инструментального обследования, Рекомендации Guidelines for the management of infective endocarditis 2015; Infective Endocarditis in Adults: Diagnosis, Antimicrobial Therapy, and Management of Complications, AHA 2015 (including update 2016).

Результаты. Пациентка, 1952 г. р., предъявляет жалобы на боль в правой стопе, лихорадку с ознобом, общую слабость. Считает себя больной в течение 3 недель. В связи с усилением боли в стопе больная бригадой скорой медицинской помощи была доставлена во многопрофильный стационар и госпитализирована в терапевтическое отделение. Анамнез жизни примечателен тем, что за полгода до госпитализации больной проводилось выскабливание полости матки по поводу полипа эндометрия. Был выставлен основной диагноз: Активный бактериальный эндокардит митрального клапана, вызванный Streptococcus haemolyticus. Митральная регургитация III ст. Хронический коронарный синдром. Сердечная недостаточность с сохраненной сократительной функцией левого желудочка (фракция выброса 68 \%). NYHA класс II. Сопутствующий диагноз: Анемия легкой степени. Реактивный артрит. Деформирующий остеоартроз голеностопного сустава. Проведенная терапия включала: меронем 1 г 3 раза в сутки в/в капельно и линезолидин 600 мг 2 раза в день per os в течение 4 недель дезинтоксикационную, кардиотропную, антиагрегантную и антикоагулянтную терапию; ингибиторы протонной помпы, диуретики, противогрибковые препараты.

Выводы. Диагностика инфекционного эндокардита составляет большие трудности, несмотря на наличие специально разработанных диагностических критериев. Учитывая полиморфизм клинических проявлений заболевания и полиорганность поражения, врачам-клиницистам следует быть 
Journal of V. N. Karazin`KhNU. 2020

настороженными в отношении инфекционного эндокардита у пациентов с соответствующими факторами риска.

КЛЮЧЕВЫЕ СЛОВА: инфекционный эндокардит, клиническая диагностика, артрит

\section{ИНФОРМАЦИЯ ОБ АВТОРЕ}

Уварова Карина Геннадьевна, ассистент кафедры пропедевтики внутренней медицины и физической реабилитации Харьковского национального университета имени В. Н. Каразина, площадь Свободы, 6, Харьков, Украина, 61022, e-mail: karinaguvarova@karazin.ua, ORCID ID: https://orcid.org/0000-0003-3135-0778 